\title{
A Methodological Evaluation of the Polish Land Administration System Using the Fit-For-Purpose Approach
}

\begin{abstract}
In the past fifteen years, many countries have been making intensive preparations towards the creation of a modern Land Administration System (LAS). These systems are a part of multi-functional spatial data infrastructure (SDI) which supports land administration. These efforts are complex since the harmonization of spatial data from various independent databases requires significant funding and time. In Poland, national LAS referred to as the Integrated Real Estate Information System (IREIS) has been developed since 2013. In light of the above, this article aims to methodologically determine whether the Polish land administration system meets fit-for-purpose criteria. The research approach takes into account the following criteria in the assessment of the Polish LAS: focus on the purpose, flexibility, ability to cover land tenure and land use, affordability, reliability in terms of information, attainability, and upgradeability with regard to incremental improvement. These criteria were estimated in three panels: spatial framework, legal framework, institutional framework. The results of our research indicate that the IREIS project has achieved global standards and is fit for purpose and they can be used to monitor the further development of the ZSIN.
\end{abstract}

Keywords: land administration system, fit-for-purpose (FFP), Integrated Real Estate Information System (IREIS), public registers, FFP approach

Received: 20 January 2020; accepted: 5 February 2020

(C) 2020 Authors. This is an open access publication, which can be used, distributed and reproduced in any medium according to the Creative Commons CC-BY 4.0 License.

1 University of Warmia and Mazury in Olsztyn, Faculty of Geoengineering, Department of Land Management and Geographic Information Systems, Olsztyn, Poland, email: agnieszka.dawidowicz@uwm. edu.pl (corresponding author)

ORCID ID: https://orcid.org/0000-0002-8445-3095

2 University of Warmia and Mazury in Olsztyn, Faculty of Geoengineering, Department of Spatial Analysis and Real Estate Market, Olsztyn, Poland, email: elzbieta.zysk@uwm.edu.pl

ORCID ID: https://orcid.org/0000-0002-2793-6154

3 University of Warmia and Mazury in Olsztyn, Faculty of Geoengineering, Department of Land Management and Geographic Information Systems, Olsztyn, Poland, email: rzrobek@uwm.edu.pl ORCID ID: https://orcid.org/0000-0003-4241-4239 


\section{Introduction}

The land administration system (LAS) is the primary source of spatial information on real estate rights, restrictions and responsibilities as part of spatial data infrastructure for the implementation of land policies and land management strategies that support sustainable development and management with the use of integrated public registers [1]. The importance of these systems has been emphasized by many publications [1-4]. Sound land administration systems linked to geospatial data deliver a range of benefits to society by supporting governance and the rule of law, alleviating poverty, securing tenure rights, supporting formal land markets, securing credit; supporting land and property taxation, protecting state land, managing land disputes, and improving land use planning and implementation. These systems enable the implementation of land policies to fulfill political and social objectives and to achieve sustainable development [5]. In light of the above, the designed LAS should cater to public needs and tasks. The LAS should be fit for purpose, i.e. it should be able to meet the needs of local communities, increase the safety of real estate and effectively support sustainable land administration $[2,4,6]$. The fit-for-purpose (FFP) concept is not new, but the main novelty lies in its contribution to the creation of sustainable land management systems $[7,8]$.

Already in 1994, Penc [9] postulated that an effective and useful spatial information system should:

- cater to current needs and account for all levels of management and decision making,

- provide comprehensive and valid information,

- provide information to recipients who need such data in a form that is suitable for direct use,

- ensure that information is used effectively, i.e. that data are valid, complete and appropriately processed,

- enable the flow of data within the shortest possible time and in accordance with the organizational structure,

- rely on digital methods to acquire, store, transfer and process data,

- be secure against the inflow of undesirable and informal data and constantly upgraded to guarantee the appropriate flow of data.

In 1983, Zmud argued [10] that every information system should be sufficiently flexible and open to modification during the development process to meet current needs and expectations (Fig. 1).

For that reason, a fit-for-purpose LAS should address the needs and problems of a given region, city and community [11, 12]. The FFP land administration system should be simple at the start with an option for improvement over time whenever necessary or relevant. This process is dynamic: purposes evolve and so do administrative systems. Owing to modern IT technologies, the LAS has practically a limitless 
functionality. Therefore, the LAS could play a major role in providing local governments with the support necessary for dealing with local problems.

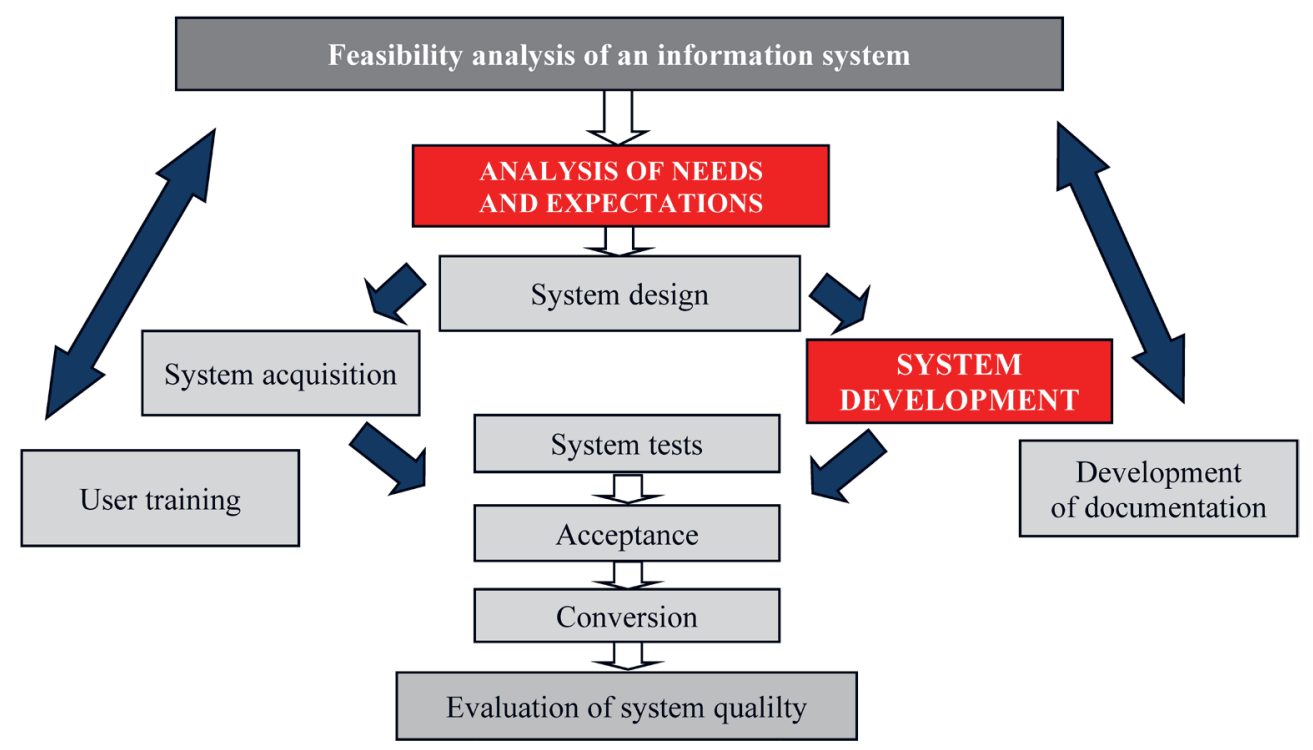

Fig. 1. Stages in the development of an information system

Source: own elaboration based on [10]

The Polish LAS, referred to as the Integrated Real Estate Information System (IREIS), has been implemented gradually since 2000. This pilot project has not yet attained its full functionality because the process of integrating data from many public registers, including the cadastre (comprehensive land records), land and mortgage register, population register, land use plans and the fiscal register, has not yet been completed. The project is co-financed by the EU, and it has to be completed within a rigid time framework in line with formal requirements. The IREIS has not yet been fully implemented, but its final shape is already beginning to emerge. At the present stage of system development, the Polish IREIS should be evaluated for compliance with the fit-for-purpose concept to ensure that it fully meets the users' needs and enables the government to apply for additional EU funds to expand the scope of the project.

In light of the above, the aim of this study was to determine whether the Polish IREIS fulfills FFP criteria in land administration. The results will be used to evaluate the quality of the IREIS project and to propose directions for further development. The LAS should be fit for the purpose, i.e. it should be able to meet the needs of local communities, increase the safety of real estate and effectively support sustainable land administration. In view of the basic tenets of the FFP approach, the authors hypothesized that the applied methodology can be used to compare and evaluate the LAS at different stages of development. 


\section{Materials and Methods}

The Polish Land Administration System, referred to as the Integrated Real Estate Information System (IREIS), was evaluated by means of an empirical study. The study was carried out with the involvement of qualitative methods (to evaluate the degree of consistency between IREIS determinants and the FFP approach) and quantitative methods (to evaluate the degree of overlap between IREIS determinants and the FFP approach). The IREIS was analyzed in view of legal regulations and government reports detailing the progress made in successive stages of system implementation.

The IREIS was evaluated based on the FFP Land Administration approach proposed by the FIG and the World Bank [2]. It was assumed that the FFP approach is appropriate for evaluating the LAS in Poland, a rapidly developing Central European country with a long history of struggle for independence which made an contribution to the collapse of communism. The degree of consistency between the IREIS and the FFP LAS model was evaluated by means of a comparative analysis. The IREIS was evaluated within spatial, legal and institutional frameworks. The current state of the Polish LAS was assessed based on the degree to which the IREIS is consistent with the core principles of the FFP approach.

\section{Results and Discussion}

\subsection{Land Administration System in Poland}

The concept of the Polish LAS was developed in 2000. The project received EU funding, and the preparations for the system's implementation began in 2013 (Tab. 1). The Polish government set out to develop the national LAS, referred to as the Integrated Real Estate Information System (IREIS), which is a multi-purpose system available to public authorities and individuals. The key assumptions for the project were adopted based on the development concepts proposed by the Williamson et al. [1], FIG [2, 13, 14] and UNECE [15-17]. The IREIS has been designed to support regular public tasks, such as tax collection, spatial planning, land partitioning, construction of infrastructure systems and public utility buildings integrating registers containing data that are most widely used by the administration to perform these daily tasks.

The IREIS is a pilot project that has not yet attained its full functionality because the process of integrating data from many public registers has not been completed. By December 2018, only 58 counties in 5 voivodships/regions (Zachodniopomorskie, Pomorskie, Dolnośląskie, Małopolskie, Podkarpackie) out of the total number of 380 counties and 16 voivodships/regions had completed the harmonization of spatial data from public registers integrated in the system. For this reason, the IREIS is presently only being tested in 58 counties (Fig. 2). 
Table 1. Land Administration System in Poland - basic information

\begin{tabular}{||l|l||}
\hline \multicolumn{1}{|c||}{ Name of system } & \multicolumn{1}{||}{ Integrated Real Estate Information System - IREIS } \\
\hline \hline System startup and milestones & $\begin{array}{l}\text { Phase I - Q3 2013 - Q3 2015 } \\
\text { Phase II - Q4 2015-Q4 2018 }\end{array}$ \\
\hline Data storage format & XML, GML 3.0 \\
\hline $\begin{array}{l}\text { Ministry / organization supervising the } \\
\text { real estate information system }\end{array}$ & $\begin{array}{l}\text { Ministers responsible for: public administration, internal } \\
\text { affairs, justice, public finances }\end{array}$ \\
\hline $\begin{array}{l}\text { Organization responsible for maintaining } \\
\text { the system at the national level }\end{array}$ & $\begin{array}{l}\text { General Surveyor of Poland in cooperation with } \\
\text { voivodeship governors and voivodeship marshals }\end{array}$ \\
\hline \begin{tabular}{l} 
Legal acts \\
\hline
\end{tabular} & ACT, 2014 [23]; Regulation, 2013 [19] \\
\hline
\end{tabular}

Source: own elaboration based on the Regulation of the Council of Ministers of 17 January 2013 on the Integrated Real Estate Information System [19] and Wysocki presentation [18]
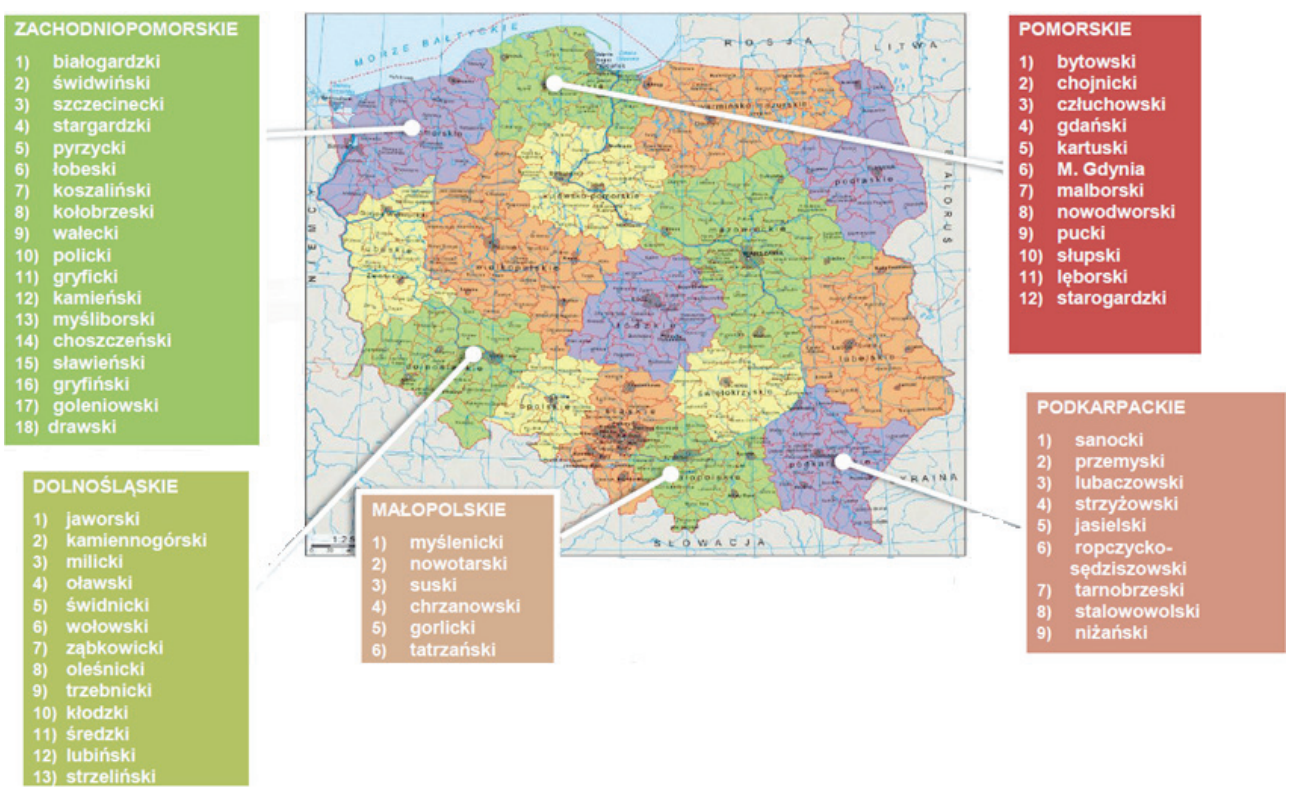

Fig. 2. Territorial coverage of the IREIS in Poland Source: own elaboration based on [18]

The IREIS is a massive undertaking, and its implementation is fraught with numerous problems, which further justifies the attempts to evaluate the project's consistency with FFP assumptions. 
The IREIS integrates many public registers (Fig. 3) through the functional specification of the Integrating Electronic Platform (IPE) which enables data to be viewed and transferred between public registers.

\section{IREIS USERS}

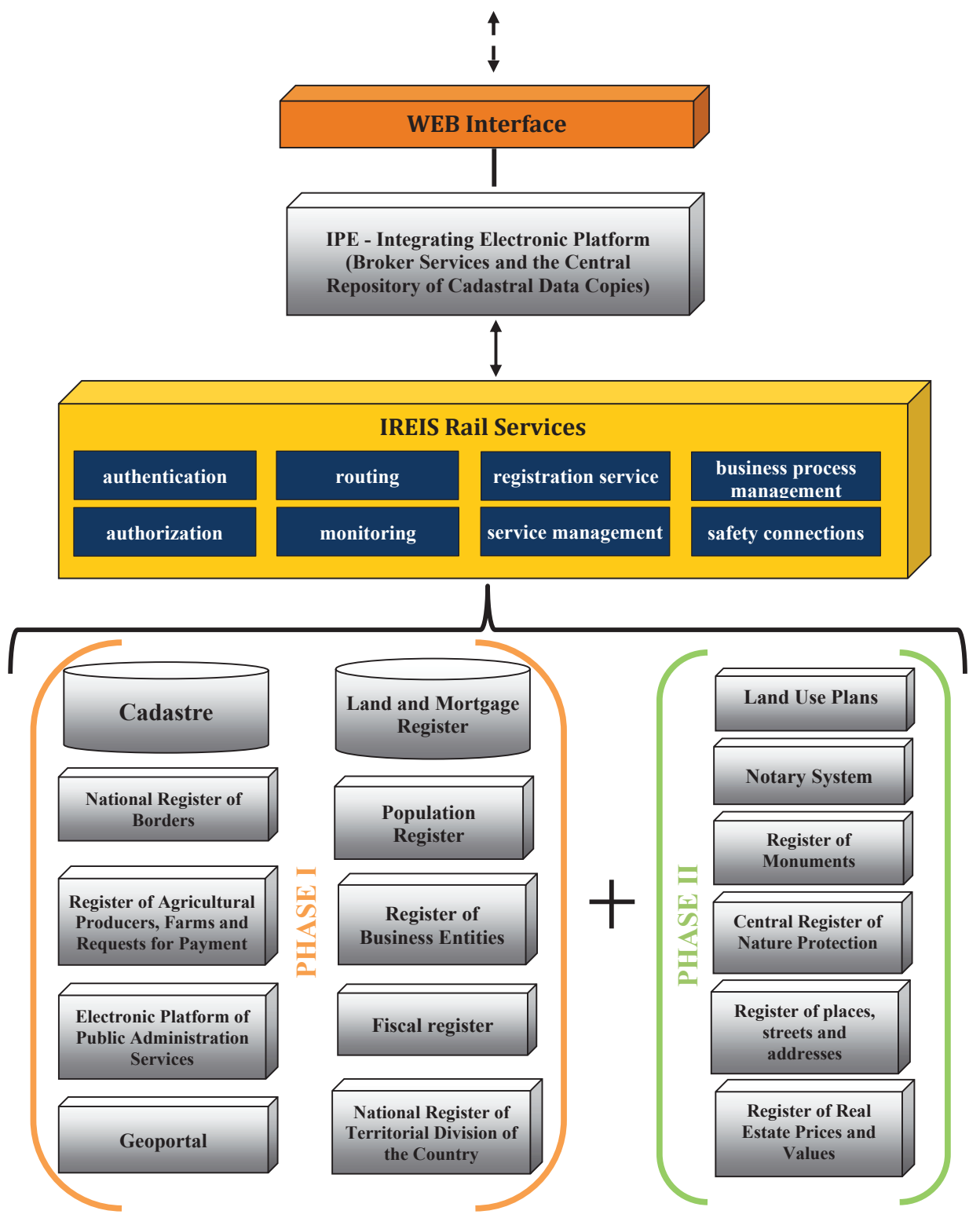

Fig. 3. Functional architecture of the IREIS 
As shown in Figure 3, seven public registers have been integrated, and two information platforms have been incorporated into the IREIS (Geoportal and the Electronic Platform of Public Administration Services) in the first stage of implementation. The IREIS has recently entered Phase II, during which successive public registers will be incorporated into the system, including Land Use Plans, Notary System, Register of Monuments, Central Register of Nature Protection, Register of places, streets and addresses, and the Register of Real Estate Prices and Values:

1) the exchange of data between the cadastre and other public records is in electronic form,

2) the tele-information system, used for the maintenance of the central repository, is to enable recording, updating and safe maintenance of data files, and making them accessible in GML formats,

3) the software employed enables visualization of data and metadata and restoring of the history of particular spatial feature,

4) the software enables automatic notifications of data changes in the cadastre,

5) access to data takes place over the Internet,

6) procedures for data conversion and cadastral database updates is implemented by a set of applications,

7) data integration is carried by the Integrating Electronic Platform (IPE),

8) the data network consists of LAN and WAN,

9) for the transformation of the source database of a cadastre into a modern cadastral database, an application that integrates the descriptive part and mapping is installed,

10) the tele-information system employed enables the performing of analyses of data files, which in particular should concern:

- preparing monthly reports with information on the number of buildings,

- performing statistical analyses concerning the utilization of data stored in registers incorporated in the IREIS system,

- performing analyses of coherence and quality of data files concerning the cadastre,

- performing spatial analyses.

Additionally, in Phase II the following e-service were developed:

1) publication of information on average transaction prices,

2) harmonization of public registers relevant for the registers incorporated into IREIS,

3) evaluation of integrity and coherence of data in the cadastre,

4) processing of spatial data in the Central Repository in combination with the data in registers relevant for other public registers incorporated into IREIS,

5) transfer of selected data and information from notarial deeds into registers incorporated into IREIS by means of standardized electronic documents. 
As shown above, the planned functionality of the LAS is to fill gaps in land information systems and to flexibly adapt to the needs of users, in particular in the field of spatial analysis, to promote the sustainable development of local municipalities. Most importantly, Spatial Data Infrastructures and the LAS are moving into a second generation [20], where the pyramid of data integration rests on local government data sharing.

\subsection{Fit-For-Purpose Land Administration Approach}

The FFP approach includes three fundamental characteristics. Firstly, there is a focus on the purpose before designing the means to be most "fit" for achieving it; secondly, the FFP approach requires flexibility in designing the means to meet the current constraints; and, thirdly, it emphasizes the perspective of incremental improvement to provide continuity [12].

A focus on purpose implies that the LAS should be designed in a manner that is most conducive to achieving a given purpose. Therefore, the notion of flexibility in designing the means to meet the current constraints fully embodies the philosophy of the FFP approach. The system should be flexible to guarantee the highest degree of accuracy and to ensure that the legal and institutional framework caters to social needs. A flexible system should also protect ownership rights, including social and customary rights as well as private ownership and tenure. Incremental improvement implies that the system should be developed in stages. The initial "minimum viable product" should be modernized and improved over time to address social and legal needs and to take advantage of business opportunities.

The FFP approach includes four core principles for each of the three frameworks (spatial, legal, institutional) (Tabs. 2-4 in Subsection 3.3).

\subsection{Evaluation of the IREIS Project in the Context of the FFP Approach}

The degree of consistency between the IREIS and the FFP approach was verified in table format in view of the key principles of the FFP approach. The presence or absence of a given determinant was denoted by a plus sign $(+, 1$ point) or a minus sign $(-, 0$ points) respectively. The total score was then calculated as the sum of points for all core principles. The chosen investigation method was further modified by adding a transitional state, denoted by the plus-minus sign (+/-, 0.5 points) representing a partial overlap of determinants.

In Table 2, IREIS determinants were compared with the key principles of the FFP approach within the spatial framework.

The comparison in Table 2 indicates that the IREIS is largely consistent with the FFP approach. The main difference is the method of identifying the boundaries of cadastral parcels in field surveys. The boundaries of more than 32 million of cadastral parcels in Poland (100\%) have been mapped with high accuracy (Fig. 4). 
Table 2. Comparison of IREIS determinants with the key principles of the FFP approach within the spatial framework

\begin{tabular}{|l|l|c||}
\hline \multicolumn{1}{|c|}{$\begin{array}{c}\text { Spatial framework } \\
\text { in the FFP approach }\end{array}$} & \multicolumn{1}{|c|}{ Spatial framework of the IREIS } & $\begin{array}{c}\text { Degree } \\
\text { of consistency }\end{array}$ \\
\hline $\begin{array}{l}\text { Visible (physical) } \\
\text { boundaries rather than } \\
\text { fixed boundaries }\end{array}$ & $\begin{array}{l}\text { Most land plots in urban areas have visible (physical) } \\
\text { boundaries that are consistent with fixed boundaries. } \\
\text { Fixed boundaries are predominant in rural areas. } \\
\text { Plot boundaries should be regulated in accordance } \\
\text { with geodetic standards. The status of land plots with } \\
\text { unregulated boundaries can be easily fixed with the } \\
\text { use of modern tools }\end{array}$ & $+/-$ \\
\hline $\begin{array}{l}\text { Aerial / satellite imagery } \\
\text { rather than field surveys }\end{array}$ & $\begin{array}{l}\text { Plot boundaries are determined based on the results } \\
\text { of field surveys and aerial or satellite imagery }\end{array}$ & + \\
\hline $\begin{array}{l}\text { Accuracy relates to } \\
\text { purpose rather than } \\
\text { technical standards }\end{array}$ & $\begin{array}{l}\text { Accuracy relates to purpose and technical standards. } \\
\text { Standards are developed for specific objectives. } \\
\text { Objects such as plot boundaries and building } \\
\text { contours are mapped with high accuracy to eliminate } \\
\text { problems during planning, construction or expansion } \\
\text { of the existing infrastructure. Another objective } \\
\text { of high accuracy is to cross reference the cadastre } \\
\text { with other information systems }\end{array}$ & + \\
\hline $\begin{array}{l}\text { Demands for updating } \\
\text { and opportunities for } \\
\text { upgrading and ongoing } \\
\text { improvement }\end{array}$ & $\begin{array}{l}\text { The system is regularly updated and upgraded. } \\
\text { Successive databases are being gradually } \\
\text { implemented in the IREIS }\end{array}$ & + Total \\
\hline
\end{tabular}

Source: own study based on the FFP approach [12]

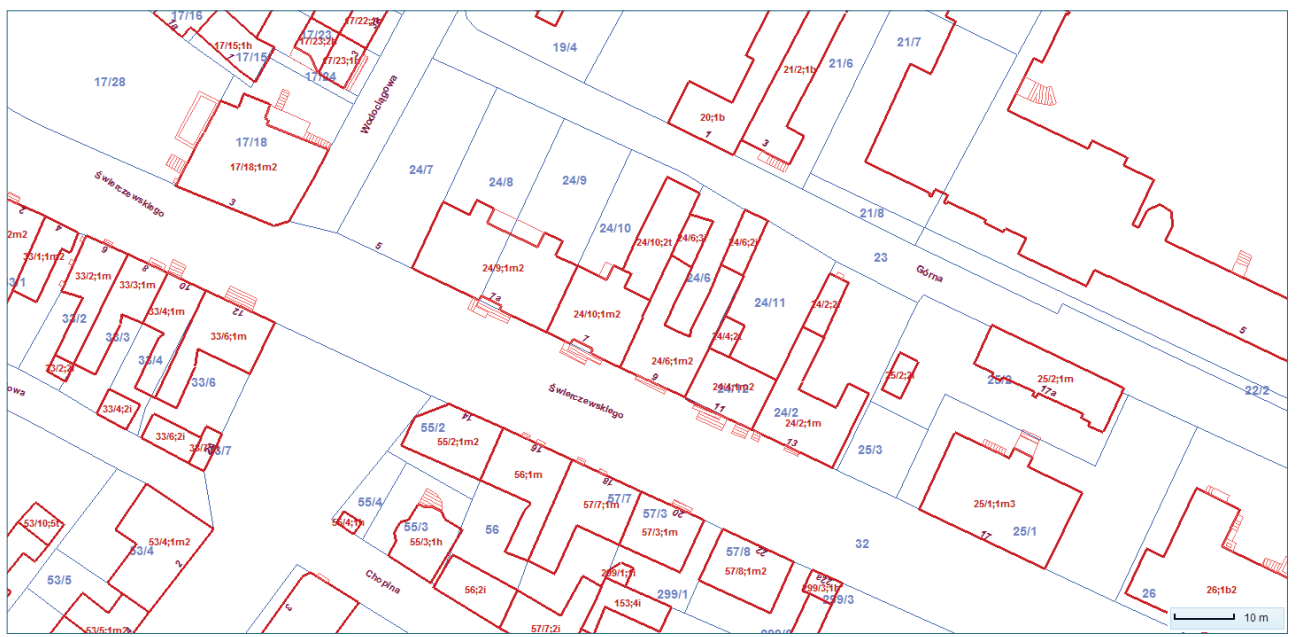

Fig. 4. Fragment of a cadastral map

Source: [21] 
The cadastral map is characterized by highly accurate terrain data, and it is regularly updated (all changes have to be entered into the cadastre as soon as possible under pain of penalty or fine), and it can serve as a reference for comparing maps from other sources (Figs. 5, 6). The above is consistent with the provisions of the Geodetic and Cartographic Law of 1989 where the cadastre is designated as a reference system for other public registers of land, buildings and premises.

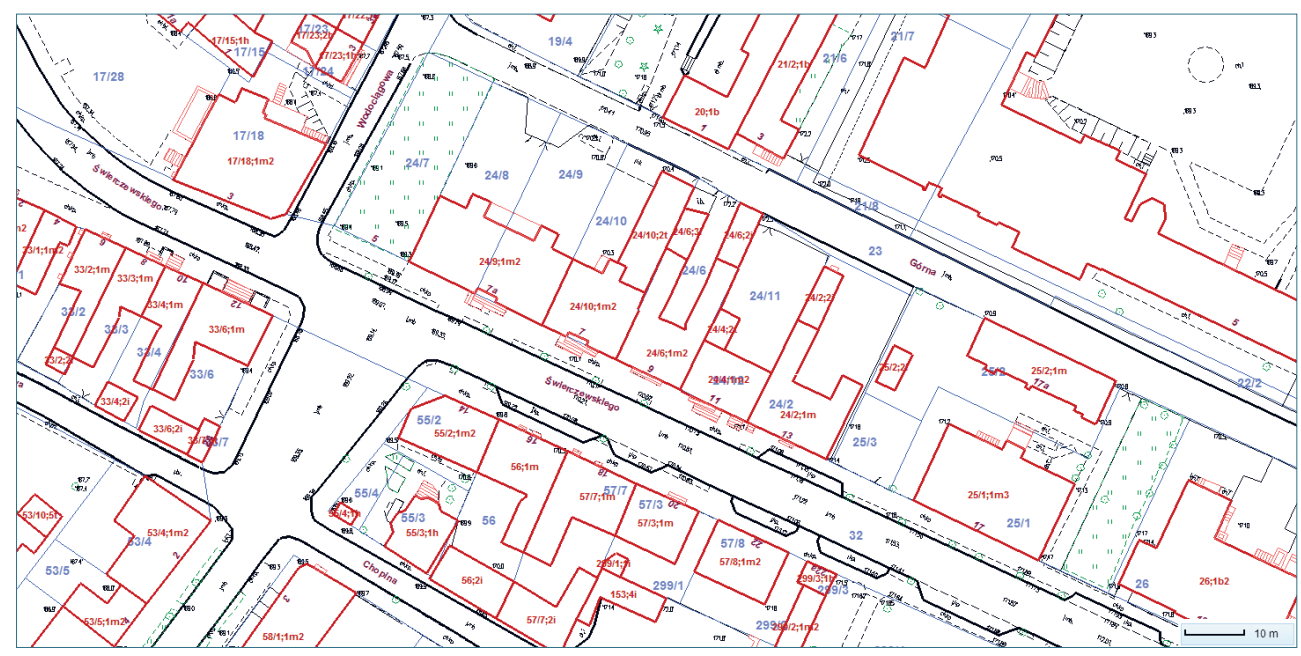

Fig. 5. Fragment of a planimetric map Source: [21]

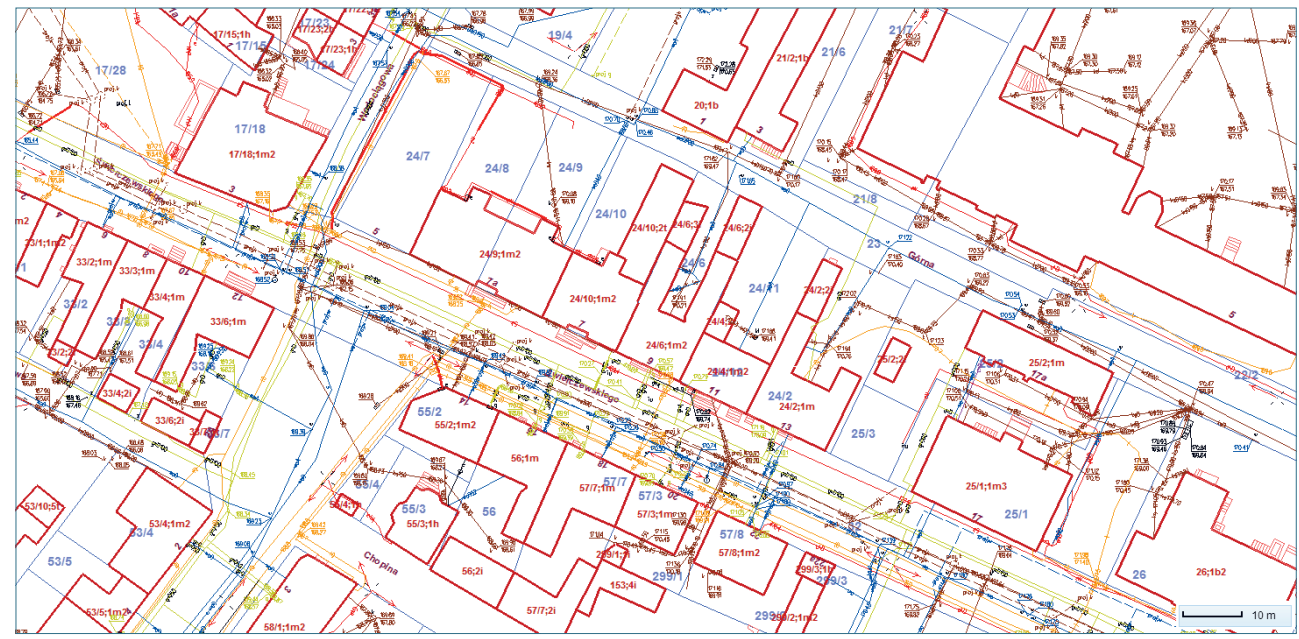

Fig. 6. Fragment of a public utilities map Source: [21] 
The high quality of the Polish cadastre is guaranteed by the law because the methods of measuring cadastral objects as well as the accuracy of those methods are defined by regulation of the Minister of Internal Affairs and Administration of 9 November 2011 on technical standards for surveying situational and altitude measurements as well as the development and transmission of the results of these measurements to the state geodetic and cartographic resources [22] and technical instructions G-5 (Cadastre) and G-4 (Planimetric and altitude measurements). According to the Regulation $\S 28, \S 29, \S 32$ [22] and $\S 71$. 1. of instruction G-5, field surveys for cadastral purposes should involve one or more of the following methods:

- polar method,

- rectangular offsets,

- differential GPS (DGPS).

In aerial and satellite images, boundaries are measured in 3D photogrammetry models with the use of stereodigital methods.

The applied measurement method must ensure that the location of terrain details relative to the nearest elements of the horizontal geodetic network is determined with an accuracy of:

- $0.10 \mathrm{~m}$ - when measuring the breakpoints of cadastral boundaries and building contours,

- $0.30 \mathrm{~m}$ - when measuring the contour breakpoints of canals, ditches and other earth structures as well as the contours of buildings measured by photogrammetric methods,

- $0.50 \mathrm{~m}$ - when measuring the contour breakpoints of:

a) land use types,

b) soil classes,

c) blocks resulting from floor differences and outlines of above-ground elements in buildings erected on pillars.

High quality requirements ensure that the Polish cadastre is sufficiently accurate to be used as a reference for other data sources. This implies that the IREIS has attained higher than anticipated accuracy standards without considerable financial inputs; therefore, the system's accuracy should not be reduced.

In Table 3, IREIS determinants were compared with the key principles of the FFP approach within the legal framework.

A cohesion analysis within the legal framework indicates that IREIS determinants are fully consistent with the FFP approach. Polish legal norms have responded dynamically to the modernization of the cadastral system in line with global trends, which indicates that the Polish legislative system is stable and fully prepared to accommodate changes. In the process of developing the Polish cadastral system, more than 80 new legal acts have been introduced directly or indirectly in the past 27 years. At the same time, more than 50 amendments have been introduced to the Geodetic and Cartographic Law [23]. 
Table 3. Comparison of IREIS determinants with the key principles of the FFP approach within the legal framework

\begin{tabular}{||l|l|c||}
\hline \multicolumn{1}{|c|}{$\begin{array}{c}\text { Legal framework } \\
\text { in the FFP approach }\end{array}$} & \multicolumn{1}{|c|}{ Legal framework of the IREIS } & $\begin{array}{c}\text { Degree } \\
\text { of consistency }\end{array}$ \\
\hline \hline $\begin{array}{l}\text { A flexible framework designed } \\
\text { along administrative rather } \\
\text { than judicial lines }\end{array}$ & $\begin{array}{l}\text { A flexible legal framework enables continuous } \\
\text { system development }\end{array}$ & + \\
\hline $\begin{array}{l}\text { A continuum of tenure rather } \\
\text { than just individual ownership }\end{array}$ & $\begin{array}{l}\text { All rights, obligations and limitations relating to } \\
\text { all types of real estate are registered. The changes } \\
\text { resulting from legal amendments are archived }\end{array}$ & + \\
\hline $\begin{array}{l}\text { Flexible recordation rather } \\
\text { than only one register }\end{array}$ & $\begin{array}{l}\text { Flexible recordation. The IREIS integrates many } \\
\text { public registers which have been designed to } \\
\text { exchange data. Therefore, data will be collected } \\
\text { only once and will be exchanged }\end{array}$ & + \\
\hline $\begin{array}{l}\text { Ensuring gender equity for } \\
\text { land and property rights }\end{array}$ & $\begin{array}{l}\text { The IREIS ensures gender equity for land and } \\
\text { property rights }\end{array}$ & + \\
\hline \multicolumn{1}{|c|}{ Total } & $4(100 \%)$ \\
\hline
\end{tabular}

Source: own study based on the FFP approach [12]

The introduced amendments addressed the following issues [24]:

- digitization of the cadastral database and the land and mortgage register;

- harmonization of the national legislation with EU laws, including interoperability sets and spatial data services;

- harmonization of cadastral sets with other data sets in the databases, including geodetic records of public utilities;

- standardizing the data sets in local cadastral databases and sharing of these data in accordance with the provisions of the Act of spatial information infrastructure;

- refining and standardizing the information in the Register of Prices and Real Estate Values;

- introducing the GML format as the standard format for the exchange and sharing of cadastral data and data from the Register of Prices and Real Estate Values;

- developing rules for classifying specific types of arable land;

- adapting owner groups and subgroups to the requirements set forth by the Act on land management;

- extending the scope of cadastral data summaries scope to include soil class data.

According to the definition of legal flexibility, where the main requirement is the preservation of continuity (changes in legal regulations in response to development) rather than sudden changes, the cadastre is characterized by unique legal flexibility. The relevant laws are amended nearly every year [24]. 
In Table 4, IREIS determinants were compared with the key principles of the FFP approach within the institutional framework.

Table 4. Comparison of IREIS determinants with the key principles of the FFP approach within the institutional framework

\begin{tabular}{|l|l|c||}
\hline $\begin{array}{l}\text { Institutional framework in the FFP } \\
\text { approach }\end{array}$ & \multicolumn{1}{|c||}{ Institutional framework of the IREIS } & $\begin{array}{c}\text { Degree } \\
\text { of consistency }\end{array}$ \\
\hline $\begin{array}{l}\text { Good land governance rather than } \\
\text { bureaucratic barriers }\end{array}$ & $\begin{array}{l}\text { The system has been created to support good } \\
\text { land governance }\end{array}$ & + \\
\hline $\begin{array}{l}\text { Integrated institutional framework } \\
\text { rather than sectorial silos }\end{array}$ & Integrated institutional framework & + \\
\hline $\begin{array}{l}\text { Flexible ICT approach rather than } \\
\text { high-end technology solutions }\end{array}$ & $\begin{array}{l}\text { The IREIS is a high-end system, which } \\
\text { integrates many dispersed databases and part } \\
\text { of the national Spatial Data Infrastructure }\end{array}$ & + \\
\hline $\begin{array}{l}\text { Transparent land information with } \\
\text { easy and affordable access for all }\end{array}$ & $\begin{array}{l}\text { The system addresses the needs of public } \\
\text { administration and provides the remaining } \\
\text { users with access to certain types of data }\end{array}$ & + \\
\hline & \multicolumn{2}{|l|}{ Total } \\
\hline
\end{tabular}

Source: own study based on [12]

The IREIS is almost fully consistent with the FFP approach in the context of the institutional framework. Information technology has been designed at a high level because it connects many different databases and systems.

The system has been created to maximize the efficiency of land administration, support public institutions and provide individuals with access to data in line with sustainable development principles [4]. The functionality of the IREIS is being gradually updated and expanded to include other real estate databases. The system has received the appropriate funding, and full functionality should be attained in the coming years. In the near future, the IREIS will substantially facilitate the operations of local and regional authorities as well as the central government.

The LAS is a much anticipated tool which will provide the public administration with support in carrying out the duties described in the Act on real estate management [25]. The Polish IREIS is used in the decision-making process.

The system has been designed to promote good governance [26]:

- IREIS is an open system; different parties can use the IREIS and the incorporated databases;

- data for the IREIS are collected by both state authorities and individuals;

- the authorities are responsible for the integration of the IREIS; the Surveyor General of Poland supervises the entire IREIS project;

- the IREIS is available at all levels of public administration and it provides businesses with comprehensive access to data from a single source; the above will shorten decision-making;

- the IREIS covers the entire country. 
The Land Administration System supports good governance, and good governance motivates the development of the LAS. Good governance cannot exist without the LAS, and there is no need for the LAS if good governance does not exist. The two systems contribute to sustainable land development.

\section{Conclusions}

A fit-for-purpose land administration requires a system that can be flexibly adapted to current needs. Needs change constantly; therefore, a system that is sufficiently flexible should also constantly evolve. The IREIS meets the above requirements because successive databases and functionalities are incorporated in stages to address new needs. The development of the IREIS project is dictated by current needs. Data from various sources are being harmonized by the local authorities, which indicates that the public administration is dedicated to the process of integrating information that plays a vital role in the performance of public tasks.

A comparative analysis revealed that the IREIS is flexible in the legal, technological and organizational context. The system has not yet achieved full functionality, and it is currently being tested in selected Polish counties.

The IREIS meets all of the evaluation criteria, including a focus on the purpose, flexibility, ability to cover land tenure and land use, affordability, reliability in terms of information, attainability, and upgradeability with regard to incremental improvement. Developmental criteria and milestones have already been attained, but the FFP approach is still highly useful for evaluating the system's usefulness. The method of presenting cadastral boundaries can be further examined in order to visualize the physical boundaries of cadastral plots.

The FFP approach was used to verify whether the Polish LAS has been developed based on sound initial assumptions. The results of the evaluation can be used to raise funds for continued project development and its incremental improvement. These measures should be initiated at the stage of the project feasibility study. The results of the study indicate that additional funds are required to harmonize and develop databases to ensure that the IREIS not only facilitates the performance of public land administration tasks, but is also accessible to individual users.

The research hypothesis postulating that the FFP approach can be used to compare and evaluate the LAS at different stages of development was thus validated. The results of the presented analysis indicate that the LAS can be flexible and well adapted to local needs even if it surpasses FFP criteria. The fact that the Polish IREIS has already attained the appropriate standards is not a disqualifying feature, but it testifies to the system's robustness. Further research is needed to develop a scale for evaluating the development of the LAS and to determine whether a land administration system can attain traits that border on perfection. 
Acknowledgments: The authors wish to thank anonymous Reviewers for their constructive comments.

Conflicts of interest: The authors declare no conflict of interest.

\section{References}

[1] Williamson I.P., Enemark S., Wallace J., Rajabifard A.: Land Administration for Sustainable Development. ESRI Press Academic, Redlands, California 2010. ISBN 978-1-58948-041-4.

[2] Enemark S., Bell K.C., Lemmen C.H.J., McLaren R.: Fit-for-purpose land administration. International Federation of Surveyors (FIG) and World Bank, Copenhagen, 2014. https://www.fig.net/resources/publications/figpub/pub60/ Figpub60.pdf [access: 6.03.2020].

[3] Lemmen C., Van Oosterom P., Bennett R.: The land administration domain model. Land Use Policy, vol. 49, 2015, pp. 535-545.

[4] Dawidowicz A., Źróbek R.: Land Administration System for Sustainable Development - Case Study of Poland. Real Estate Management and Valuation, vol. 25, no. 1, 2017, pp. 112-122. https://doi.org/10.1515/remav-2017-0008.

[5] United Nations Committee of Experts on Global Geospatial Information Management the Application of Geospatial Information - Land Administration and Management UN-GGIM Version 3.1, 13 July 2015.

[6] Bennett R.M., Alemie B.K.: Fit-for-purpose land administration: lessons from urban and rural Ethiopia. Survey Review, vol. 48, issue 346, 2016, pp. 11-20.

[7] Enemark S.: Sustainable land governance: spatially enabled, fit for purpose and supporting the global agenda. [in:] Proceedings of Annual World Bank Conference on Land and Poverty, 23-26 April 2012, Washington D.C., USA. https://www. forskningsdatabasen.dk/en/catalog/2389363812 [access: 6.03.2020].

[8] McLaren R., Enemark S., Lemmen C.: Guiding Principles for Building Fit-For-Purpose Land Administration Systems in Developing Countries: Capacity Development, Change Management and Project Delivery. [in:] Recovery from Disater: FIG Working Week 2016, Christchurch, New Zealand, 2-6 May, 2016, FIG International Federation of Surveyors, 2016. https://www.researchgate.net/ publication/303696699_Building_Fit-For-Purpose_Land_Administration_ Systems_Guiding_Principles [access: 6.03.2020].

[9] Penc J.: Informacyjny system zarzadzania firma. Zeszyty Naukowe. Organizacja i Zarządzanie/Politechnika Łódzka, z. 25, nr 698, 1994, pp. 39-51.

[10] Zmud R.W.: Information Systems in Organizations. Addison-Wesley Longman Publishing, Boston 1983.

[11] Dawidowicz A., Źróbek R.: A methodological evaluation of the Polish cadastral system based on the global cadastral model. Land Use Policy, vol. 73, 2018, pp. 59-72. https://doi.org/10.1016/j.landusepol.2018.01.037. 
[12] EnemarkS., McLaren R., Lemmen C.: Fit-For-Purposeland administration-guiding principles. GLTN Reference Document, 2015. https://www.researchgate. net/profile/Christiaan_Lemmen/publication/288503469_Fit-For-Purpose_ Land_Administration_Guiding_Principles/links/568250fa08aebccc4e0cf82a. pdf [access: 6.03.2020].

[13] FIG Statement on the Cadastre 1995. FIG Publication No. 11, FIG Office, Copenhagen. http://www.fig.net/commission7/reports/cadaster/statement_on_ cadaster.html [access: 5.12.2010].

[14] Kaufmann J., Steudler D.: Cadastre 2014. A vision for a future cadastral system. FIG - Commission 7 Working Group, 1998.

[15] Land Administration Guidelines. UNECE, Committee on Human Settlements, Geneva 1996.

[16] Guidelines on real property units and identifiers. UNECE, Geneva 2005.

[17] Land administration in the UNECE region. Development trends and main principles. UNECE, Geneva 2005.

[18] Wysocki J.: ZSIN - Budowa Zintegrowanego Systemu Informacji o Nieruchomościach - Faza I. Warszawa, 30.11.2015. http://www.gugik.gov.pl/_data/ assets/pdf_file/0004/24475/2.-ZSIN-Budowa-Zintegrowanego-Systemu-Informacji-o-Nieruchomosciach-Faza-I.pdf [access: 21.06.2018].

[19] Rozporzadzenie Rady Ministrów z dnia 17 stycznia 2013 r. w sprawie zintegrowanego systemu informacji o nieruchomościach. Dz.U. 2013 poz. 249 [Regulation of Council of Ministers of 17 January 2013 on the Integrated Real Estate Information System. Journal of Laws of 2013, item 249].

[20] Harvey F., Tulloch D.: Local-government data sharing: Evaluating the foundations of spatial data infrastructures. International Journal of Geographical Information Science, vol. 20, 2006, pp. 743-768.

[21] Geoportal2. http://powiatolsztynski.geoportal2.pl/map/www/mapa.php? CFGF=wms\&mylayers=+granice+OSM+ [access: 15.02.2019].

[22] Rozporzadzenie Ministra Spraw Wewnętrznych i Administracji z dnia 9 listopada 2011 r. w sprawie standardów technicznych wykonywania geodezyjnych pomiarów sytuacyjnych $i$ wysokościowych oraz opracowywania i przekazywania wyników tych pomiarów do państwowego zasobu geodezyjnego i kartograficznego. Dz.U. 2011 nr 263, poz. 1572 [Regulation of the Minister of Internal Affairs and Administration of 9 November 2011 on technical standards for surveying situational and altitude measurements as well as the development and transmission of the results of these measurements to the state geodetic and cartographic resources. Journal of Laws of 2011, No. 263, item. 1572]

[23] Ustawa z dnia 5 czerwca 2014 r. o zmianie ustawy - Prawo geodezyjne $i$ kartograficzne oraz ustawy o postępowaniu egzekucyjnym w administracji. Dz.U. 2014, poz. 897 [Act of 5 June 2014 amending the Act - Geodetic and Cartographic Law and the Act on enforcement proceedings in administration. Journal of Laws of 2014, item. 897]. 
[24] Dawidowicz A., Klimach A., Źróbek R.: Dynamics of Legal Changes in Polish Cadastre. [in:] Ivan I., Horák J., Inspektor T. (eds.), Dynamics in GIscience. Lecture Notes in Geoinformation and Cartography, Springer, Cham 2017, pp. 57-69. https://doi.org/10.1007/978-3-319-61297-3_5.

[25] Ustawa z dnia 21 sierpnia 1997 r. o gospodarce nieruchomościami. Tekst ujednolicony: Dz.U. 2018, poz. 121 [Act of 21 August 1997 on real estate management. Consolidated text: Journal of Laws of 2018, item. 121].

[26] Klimach A., Dawidowicz A., Źróbek R.: The Polish land administration system supporting good governance. Land Use Policy, vol. 79, 2018, pp. 547-555. https://doi.org/10.1016/j.landusepol.2018.09.003.

\section{Metodologiczna ocena polskiego systemu administrowania nieruchomościami z zastosowaniem podejścia Fit-For-Purpose}

Streszczenie: W ciągu ostatnich piętnastu lat wiele krajów prowadziło intensywne przygotowania do stworzenia nowoczesnego systemu administrowania nieruchomościami (LAS - Land Administration System). System ten stanowi część wielofunkcyjnej infrastruktury danych przestrzennych (SDI - Spatial Data Infrastructure), która wspiera administrację nieruchomościami. Wysiłki te są złożone, ponieważ harmonizacja danych przestrzennych z różnych niezależnych baz danych wymaga znacznych nakładów finansowych i czasu. W Polsce od 2013 roku tworzony jest krajowy system administrowania nieruchomościami, nazywany zintegrowanym systemem informacji o nieruchomościach (ZSIN). Niniejszy artykuł ma na celu metodologiczną ocenę polskiego LAS i sprawdzenia czy spełnia on kryteria użyteczności (dostosowania do potrzeb). Podejście badawcze uwzględnia następujące kryteria w ocenie polskiego systemu LAS: koncentracja na celu, elastyczność, rejestrowanie praw własności i użytkowania gruntów, przystępność cenowa, wiarygodność informacyjna, dostępność i możliwość elastycznej modernizacji. Kryteria te zostały oszacowane w trzech panelach, tj.: ramy przestrzenne, ramy prawne i ramy instytucjonalne. $\mathrm{Wy}_{\mathrm{-}}$ niki badań autorów wskazują że projekt IREIS osiągnął światowe standardy i może być wykorzystywany do monitorowania dalszego rozwoju ZSIN.

\section{Słowa}

kluczowe: system administrowania nieruchomościami, dostosowanie do potrzeb, zintegrowany system informacji o nieruchomościach (ZSIN), rejestry publiczne, podejście FFP 